原著論文

咬頭嵌合位の咬合接触数と最大咬みしめ時の顎筋

ならびに胸鎖乳突筋筋活動との関連性

大沼 典男 ${ }^{a}$ 猪子 芳美 ${ }^{b}$ 森田 修已 ${ }^{b}$

\title{
Relationship between the Number of Occlusal Contacts in Intercuspal Position and the Jaw and the Sternocleidomastoid Muscle Activities during Maximum Voluntary Teeth Clenching
}

\author{
Norio Ohnuma, DDS, $\mathrm{PhD},{ }^{a}$ Yoshimi Inoko, DDS, $\mathrm{PhD},{ }^{\mathrm{b}}$ and Osami Morita, DDS, $\mathrm{PhD}^{\mathrm{b}}$
}

抄 録

目的：咬頭嵌合位における咬合接触数と咬合機能時の顎頸部筋活動との関連性を筋電図にて検討する. 方法：両側臼歯部の咬合支持を有する健常者 20 名（女性 7 名，男性 13 名）の咬頭嵌合位における最大咬 みしめ (MVC) と両側田歯部コットンロール介在の最大咬みしめ (With MVC), 各々 3 秒間の咬筋 $(\mathrm{Mm})$, 側頭筋前部 (Tp), 顎二腹筋前腹 (Dig), 胸鎖乳突筋 $(\mathrm{SCM})$ の筋活動を記録した。分析は咬頭嵌合位での咬合 接触数多数群（咬合接触点 9 以上: MG） と咬合接触少数群（咬合接触点 8 以下: FG）に分類 L, MVC 時の各筋間での相対的筋活動 (MVC/ With MVC) の比較は Friedmanの検定，筋間の相関関係は Spearman の順位相関, 各筋の With MVC と MVC 時の筋活動は Wilcoxon の順位検定, FG と MG にお ける MVC 時の各筋の相対的筋活動の比較は Mann-WhitneyのU 検定を用いた。

結果: MVC 時の Mm, Dig, SCM の筋活動は With MVC 時と比較して 11 14\%減少し，相対的筋活動は, Mm と Tp, Dig, SCM との間に正の相関を認めた。Mm は, MVCがWith MVC に比べて有意に小さい值 を示した。相対的筋活動は Mm, Tp, SCM において MG が FG に比べて有意に大きい值を示した.

結論：MVC 時における Mm, Tp, SCM の筋活動は咬頭嵌合位の咬合接触数によって変化することが示唆 された。

和文キーワード

咬合接触，顎筋，胸鎖乳突筋，表面筋電図

\section{I 。緒言}

顎口腔系における通常の機能活動は上下顎歯列間の 安定した咬合接触を必要とする ${ }^{1)}$ 。上下顎の歯が最も多 くの部位で接触し，安定したときの下顎位，すなわち咬 頭嵌合位は下顎位にとって最も重要な位置である ${ }^{2}$.

これまでに咬合接触と閉口筋の筋電位の振幅, 筋収縮 活動の持続時間との関連が報告されている ${ }^{3-5)}$. 下顎運 動は開口筋および閉口筋が主体をなし ${ }^{6,7)}$ ，さらに頸部
筋 ${ }^{8-11)}$ 等も複雑に関与している. 特に開口筋および閉口 筋は拮抗筋として作用し協調性を保っているが，胸鎖乳 突筋（SCM）との関連は十分に明らかにされていない. このことから閉口筋による機能評価のみならず開口筋 と頸部姿勢筋である SCM の働きとの関連についても検 討する必要がある。

顎二腹筋前腹（Dig）は顎舌骨筋，オトガイ舌骨筋， 茎突舌骨筋と共同して働き開閉口，舌運動，嚥下などに 関与する開口筋であるが開口に当たっては大きな筋力 を必要とせずに閉口筋の弛緩と下顎の重さの助けを受

a 日本歯科大学新潟病院総合診療科（主任：宇野 清博教授）

${ }^{\mathrm{b}}$ 日本歯科大学新潟生命歯学部歯科補綴学第 3 講座（指導 : 森田 修己教授)

${ }^{a}$ Department of Comprehensive Dental Care, The Nippon Dental University Niigata Hospital

${ }^{\mathrm{b}}$ Department of Complete Denture, The Nippon Dental University, School of Life Dentistry at Niigata 受付 : 2008 年 3 月 10 日/受理 : 2008 年 9 月 27 日

Received on March 10, 2008/Accepted on September 27, 2008 
けながら開口動作を行っていると考えられている ${ }^{12)}$. 一方，SCM は鎖骨および胸骨から起こり側頭骨乳様 突起および後頭骨に停止する外側頸筋であり, 顎機能 時には僧帽筋とともに頭部の運動，定位に関与してい $3^{9,10)}$. SCM は咀嚼筋の範疇に含まれないが，咬合機 能時に EMG 活動がみられること ${ }^{9-11)}$, 顎機能障害の 症状との関連があることなど歯科臨床において関連の 深い筋である ${ }^{13)}$ 。 また筋電図学的研究によって咀嚼運 動時に見られるSCM の活動は閉口筋に比例する様相

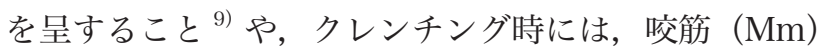
や側頭筋（Tp）などの咀嚼筋活動とは全く異なる活動 様相を呈する事が報告されている ${ }^{14)}$ が，咬頭嵌合位に おける咬合接触数との関連は明らかにされていない.

そこで本研究は，健常有歯顎者の咬頭嵌合位における 最大咬みしめ (MVC) 時の Mm，Tp 前部，Dig ならび に SCM の筋活動量と咬合接触数との関係を検討するこ とを目的とする。

\section{II. 研究方法}

\section{1. 被験者}

被験者は，歯学部学生および歯科臨床研修医のなかか ら第三大白歯以外は久損を認めず，両側臼歯部の咬合支 持を有し，顎機能に自覚的および他覚的に異常を認めな い $22 \sim 28$ 歳の 20 名（男性 13 名，女性 7 名，平均年 齢 $24.3 \pm 1.9$ 歳）を選択した。全被験者には本研究の 主旨と内容を十分に説明し同意を得た。なお，この研究 は日本歯科大学新潟生命歯学部倫理委員会の承認（受付 番号：46）を得た後に開始した。

\section{2. 咬合接触の記録と検出}

咬合接触の記録は背を真つ直ぐにした状態で歯科用 治療椅子に被験者を座らせ厚さ $12 \mu \mathrm{m}$ の咬合紙 Occlusion Foil $^{\circledR}$ (single side/green Lot.97496.GH HANAL Germany）をホルダーで保持し，中程度の力 で軽く咬頭嵌合位で閉口するいわゆるタッピング運動 を練習させた後に行った。咬合接触の記録は 3 回のタッ ピング運動時の上顎歯列咬合面をデジタルカメラ (EOS Kiss D DCC5- LV, Canon) で記録，保存した。咬合接 触数の評価，検出は著者の 1 人が $\mathrm{PC}$ 画面上で行った。

\section{3. 表面筋電図の記録と測定}

表面筋電図はデジタル EMG 記録装置（Muscle Tester ME 3000 P, Mega Electronics Ltd, Kuopio, Finland) と 血状表面電極（Blue sensor, type-N-00-S, Medico test A/S. Osyka，Denmark）を使用し，Mm, Tp, Dig および

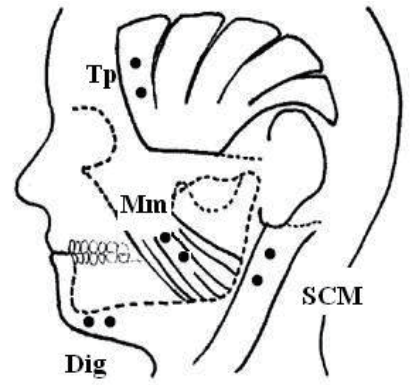

図 1 Bipolar surface electrodes positioned on the $\mathrm{Mm}$, Tp, Dig, and SCM

Mm: masseter muscle, Tp: temporalis muscle, Dig: anterior- belly of the digastric muscle, SCM: sternocleidomastoid muscle

$\mathrm{Mm}, \mathrm{Tp}, \mathrm{Dig}$ ならびに SCM における電極の貼付 位置

Mm: 咬筋，Tp: 側頭筋前部，Dig: 顎二腹筋前腹, SCM: 胸鎖乳突筋

SCM の筇電図記録を行った。あらかじめ習慣性咀嚼側 （利き側）を聴取し，利き側の Mm, Tp, Dig, SCM を被 験筋とした。電極貼付位置は，筋の走行に平行として $\mathrm{Mm}$ は浅層中央部，Tp は前部，Dig では前腹， $\mathrm{SCM}$ は乳様突起より下方 $10 \mathrm{~mm}$ とた。電極間距離は $20 \mathrm{~mm}$ とした（図 1)。電極貼付位置をアルコールガーゼでよ く清拭してから電極を貼付した.また, 電極の伝導性ぺー ストを十分に皮膚に湿潤させるために 5 ～ 6 分たって から計測を開始した。被験者には，背板を起こした歯科 用椅子上にて，頭部を固定せずリラックスした状態でフ ランクフルト平面が水平になるような頭位をとらせた。 被験運動は、EMG 電位を標準化するために，各被験者 の下顎小臼歯と大臼歯咬合面にコットンロール $(\mathrm{Hi}-$ Dentalmen ${ }^{\circledR} ， \Phi 10 \mathrm{~mm} \times 30$ mm，イワッキ）を両側に介 在させた状態での最大咬みしめ (With MVC) と MVC の 2 方法とした。被験運動時間は 3 秒間とし，それぞ れ 3 回行わせた. EMG 活動記録のデー夕分析は付属の ソフトウェア (Muscle Tester ME 3000P. Software V2.1- program, Mega Electronics Ltd, Kuopio, Finland) を用いて MVC ならびに With MVC 時の各筋の EMG 積 分值を算出した。筋の疲労による影響を考慮し試行間隔 を十分に取り, 安静電位に戻ってから繰り返し測定を 行った.

\section{4. データ分析}

3 回のタッピング運動時に上顎前歯部舌面ならびに, 臼歯部咬合面に印記された咬合接触数は，一歯あたりの 咬合接触点数を合計したもので，咬合接触点数 9 以上が 10 名（男性 8 名，女性 2 名)，咬合接触点数 8 以下が 


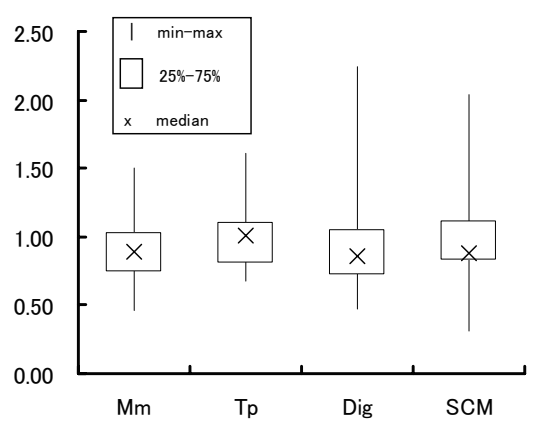

図 2 EMG median value in each muscle 各筋の相対的筋活動 (MVC/With MVC)

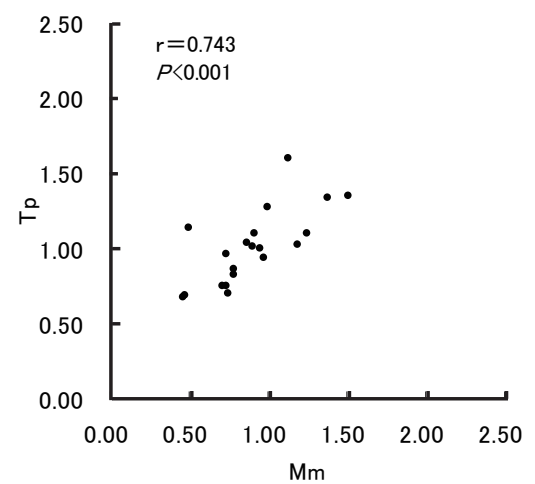

図 3-1 Correlation between Mm and Tp EMG activity $\mathrm{Mm}$ と Tp の相対的筋活動 (MVC/ With MVC) と の相関

10 名（男性 5 名，女性 5 名）であった。これにより各 被験者を咬合接触多数群 (MG: multiple contacts group) 10 名と咬合接触少数群 (FG: few contacts group） 10 名の 2 群に分類した。

各筋間における相対的筋活動 (MVC/ With MVC) の 比較は Friedmanの検定を，各筋間の相関関係は Spearman の順位相関を用いて調べた。

Mm, Tp, Dig, SCM における With MVC と MVC 時の 筋活動との関係は Wilcoxon の順位検定を用いて調べ た.

FG と MG における各筋の相対的筋活動の比較は Mann-Whitney の U 検定を行った。統計解析は危険率 5\%とした.

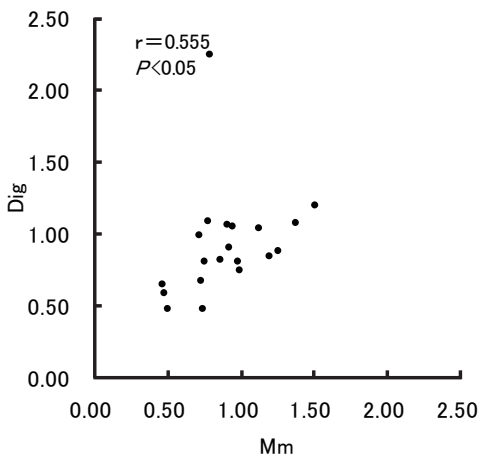

図 3-2 Correlation between Mm and Dig EMG activity $\mathrm{Mm}$ と Dig の相対的筋活動 (MVC/ With MVC) と の相関

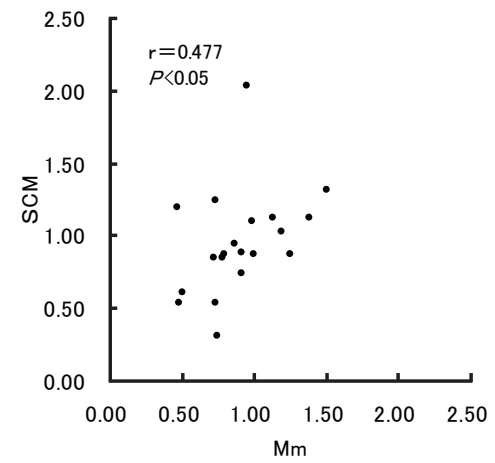

図 3-3 Correlation between Mm and SCM EMG activity $\mathrm{Mm}$ と SCM の相対的筋活動 (MVC/ With MVC) との相関

III. 結 果

1. Mm, Tp, Dig, SCM における相対的筋活動 (MVC/ With MVC)

各筋の中央值と四分位範囲 (IQR) を図 2 に示す。 $\mathrm{Mm}$ の中央值は 0.89, Tp では 1.01, Dig では 0.86, SCM では 0.88 であった。各筋間には有意差を認めなかった。

2. Mm, Tp, Dig, SCM における相対的筋活動 (MVC/ With MVC) の相関関係

図 3-1 に Mm と Tp，図 3-2 に Mm と Dig，図 3-3 に $\mathrm{Mm}$ と SCM の散布図と相関係数ならびに $\mathrm{P}$ 值を示す。 $\mathrm{Mm}$ と Tp 間に強い相関 $(\mathrm{r}=0.743, \mathrm{P}<0.001)$ を，ま た $\mathrm{Mm}$ と Dig 間 $(\mathrm{r}=0.555, \mathrm{P}<0.05), \mathrm{Mm}$ と $\mathrm{SCM}$ 間 $(\mathrm{r}=0.477, \mathrm{P}<0.05)$ に相関を認めた。しかし，Tp と Dig 間 $(r=0.343), T p と S C M$ 間 $(r=0.283)$, Dig と $\mathrm{SCM}$ 間（r=0.224）には相関を認めなかった. 
表 1 Median and IQR of EMG activity in each muscle during MVC and With MVC

MVC: maximum voluntary clenching, With MVC: maximum voluntary clenching on cotton rolls positioned on the posterior teeth

MVC と With MVC における各筋の筋活動の中央 值と四分位範囲 MVC: 最大咬みしめ, With MVC: 両側臼歯部コットンロール介在の最大咬み しめ

\begin{tabular}{|c|c|c|c|c|}
\hline \multicolumn{2}{|c|}{ MVC } & \multicolumn{2}{|c|}{ With MVC } & $P$-value \\
\hline Mm 168.00 & (109.92) & 182.50 & (108.50) & $P<0.05$ \\
\hline Tp 144.50 & (98.58) & 168.83 & $(62.42)$ & NS \\
\hline Dig 15.33 & $(10.25)$ & 20.00 & (12.83) & NS \\
\hline SCM 21.83 & (12.08) & 25.00 & (16.92) & NS \\
\hline
\end{tabular}

3. With MVC と MVC 時における Mm, Tp, Dig, SCM の EMG 活動量

表 1 に With MVC と MVC 時における Mm, Tp, Dig, SCM の筋活動の中央値と四分位範囲を示す，MVC 時の 中央值と四分位範囲は，Mmでは 168.00 (109.92) $\mu \mathrm{V}, \mathrm{Tp}$ では 144.50 (98.58) $\mu \mathrm{V}$, Dig では 15.33(10.25)

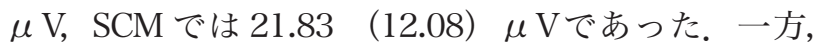
With MVCでは Mm は 182.50 (108.50) $\mu \mathrm{V}, \mathrm{Tp}$ で は 168.83 (62.42) $\mu \mathrm{V}$, Dig では 20.00 (12.83) $\mu \mathrm{V}$, SCM では 25.00 （16.92） $\mu \mathrm{V}$ であった. Mm では有意 水準 0.05 で MVC が With MVCに比べて小さい值を示 したが，TpとDig，SCMにおいてはMVCと With MVC との間に有意差を認めなかった。

\section{FG と MG における Mm，Tp，Dig，SCM の相 対的筋活動 (MVC/ With MVC)}

表 2 に各筋の FG と $\mathrm{MG}$ における中央値と四分位範 囲をしめす. Mm における $\mathrm{FG}$ と $\mathrm{MG}$ の中央值と四分 位範囲はそれぞれ 0.76 (0.29), 1.06 (0.31), Tp では 0.84 (0.29), 1.10 (0.31), Dig では 0.81 (0.36), 0.89 (0.28), SCM では 0.85 (0.28), 1.07 (0.34) であり, Mm と $\mathrm{Tp}, \mathrm{SCM}$ においては有意水準 0.05 で MG が FG に比 べて大きい值を示した. Dig においては $\mathrm{MG}$ と FG との 間に有意差を認めなかった。

\section{IV. 考 察}

\section{1. 研究方法について}

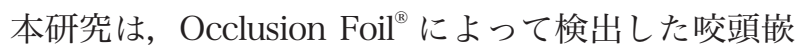
合位の咬合接触数と MVC 時の Mm，Tp，Dig ならびに
表 2 Median and IQR of EMG activity in each muscle on $\mathrm{MG}$ and $\mathrm{FG}$

MG: multiple contacts group, FG: few contacts group

MG と FGにおける各筋の相対的筋活動 (MVC/ With MVC) の中央値と四分位範囲 $\mathrm{MG}$ : 咬合接触多数群, $\mathrm{FG}$ : 咬合接触少数群

\begin{tabular}{llcc}
\hline & FG & MG & $P$-value \\
\hline $\mathrm{Mm}$ & $0.76(0.29)$ & $1.06(0.31)$ & $P<0.05$ \\
$\mathrm{Tp}$ & $0.84(0.29)$ & $1.10(0.31)$ & $P<0.05$ \\
$\mathrm{Dig}$ & $0.81(0.36)$ & $0.89(0.28)$ & $\mathrm{NS}$ \\
$\mathrm{SCM}$ & $0.85(0.28)$ & $1.07(0.34)$ & $P<0.05$ \\
\hline
\end{tabular}

SCM における EMG 筋活動との関係を健常有歯顎者に おいて分析した.

咬頭嵌合位の咬合接触は，下顎運動，頭位，体位，咬 合力，時刻などの要因 ${ }^{15-19)}$ を考慮する必要がある。本 研究では測定時間帯は 18-19 時の間に行い, 頭位, 体 位は一定条件下にて行った。咬合接触数と咬合接触面積 は咬合力によって大きく影響される。そこで被験運動時 の咬合力を規制するために下顎安静位からの軽い夕ッ ピング運動を指示し，その $\mathrm{EMG}$ 波形を視覚的にフィー ドバックして練習させてから習慣性閉口運動 1 回, タッ ピング運動 3 回と 5 回の咬合接触を記録した。タッピ ング運動回数間の咬合接触数の比較には Friedman の検 定を用いた。その結果，3回と 5 回の咬合接触数には有 意差が認められなかったのでタッピング 3 回時の咬合 接触を代表値とした。

咬合接触の検査 ${ }^{3)}$ には咬合紙, シリコーンブラック, オクルーザルインジケーターワックス ${ }^{\circledR}$ な゙のワックス, 咬合接触とともに咬合圧が測定できるデンタルプレス ケール®や T-Scan ${ }^{\circledR}$ などがある。これらの方法の中でと りわけ $10 \mu \mathrm{m}$ 程度のストリップスを上下歯列間に介在さ せ，咬頭嵌合位や偏心位で咬合させ 1 歯ずつの引き抜き によって咬合接触を検査する引き抜き試験法が最も正確 で，信頼性と再現性に優れているといわれている ${ }^{15,16)}$. Hidaka ら ${ }^{5)}$ はデンタルプレスケール ${ }^{\circledR}$ を用いて咬合接 触域の増加と咀嚼筋力が比例することを明らかにしてい

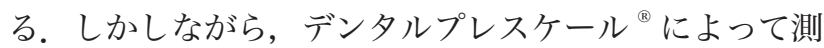
定された咬合接触には多くの問題点が含まれている ${ }^{20)}$. 例えばフィルムの厚さと剛性は歯の固有咬合に互いに 影響しあい, 誤った情報が生じていると考えられている. そこで本研究では習慣性閉口位の咬合接触を $12 \mu \mathrm{m}$ の 咬合紙を用いて検出した。この咬合紙の厚さ $12 \mu \mathrm{m}$ は 天然歯列の臼歯部における咬合物質の厚さ知覚閾の最 
小值 ${ }^{21)}$ に近似していることなどからより適正な咬合接 触が得られたものと考える。

本研究では咬頭嵌合位における咬合接触数と EMG 活 動との関連性を調べるために, 被験者を咬合接触数少数 群 (FG: few contacts group) と多数群 (MG: multiple contacts group）の 2 群に分けて分析した. 2 群間の境 界咬合接触数 8 は 20 被験者の中央值であったことから

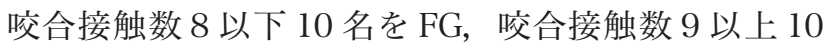
名を $\mathrm{MG}$ とした。

本研究における被験筋は Mm, Tp, Dig と SCM を選 択した. SCM は体幹と頭蓋との間に走行し, 咬合機能 時には頸部を体幹に固定することが要求されること ${ }^{22)}$, 咬合異常が原因で生ずる SCM の疼痛が筋停止部に高頻 度に見られること ${ }^{13)}$ などを勘案して SCM を被験筋と した. SCM への電極貼付位置については SCM 停止部 が筋中央部に比較し, 咬合力の変化に敏感に反応して活 動していること ${ }^{10)}$ ，咬合異常が原因で生ずる SCM の疼 痛が筋停止部に高頻度に見られること ${ }^{13)}$ などから筋停 止部とし, 乳様突起の下方 $10 \mathrm{~mm}$ とした. EMG 積分 值は被験者および被験筋ごとに異なり, EMG 積分值の 絶対值を直接比較することはできない，本研究は，咬合 接触数と咬合機能時における顎筋および頸部筋の筋活 動の関連性を明らかにすることを目的とすることから， 咬合接触を除いた状態を基準と考えた。そこで咬頭嵌合 位における MVC 時の EMG 電位は，標準化試験（コッ トンロール介在下の最大咬みしめ：With MVC) で記録・ 測定された平均電位に対する割合 (MVC/ With MVC) として表示し，各被験筋間ならびに FG と $\mathrm{MG}$ 間の分 析に用いた。相対的筋活動（MVC/ With MVC）を使用 することで, 被験者間による違い（電極の貼り付け位置, 皮膚と電極間のインピーダンス, 被験筋の発達度合い) を標準化した。これにより被験者間の EMG 積分值を同 一カテゴリー内で取り扱うことが可能になった。

\section{2.結果について}

1) Mm, Tp, Dig, SCM における相対的筋活動（MVC/ With MVC)

相対的筋活動の中央值は $\mathrm{Mm}$ では 0.89, Tp 1.01， Dig 0.86, SCM 0.88 であり, 各筋間に有意差は認めら れなかった. MVC 時の Mm, Dig, SCM の筋活動は With MVC 時に比べて $11 〜 14 \%$ 減少した。一方，Tp の筋活動はWith MVC 時に比べて MVC 時に 1\%増加し, 変化量の差から, Tp の筋活動はコットンロールの介在 による影響が Mm, Dig, SCM に比べて少ないと言える。 $\mathrm{Tp}$ の筋活動変化が少なかった理由として, Tpの筋活 動は後方位で咬頭嵌合位の約 2 倍, 前方位では急減す

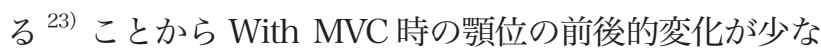
かったことによるものと考える。一方， $\mathrm{Mm}$ の筋活動

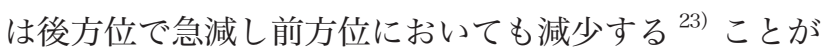
示されている. したがってWith MVC 時の筋活動に比 較して MVC 時の Mm の筋活動の減少は咬合高径の僅 かな変化（減少）に起因するものと考える. 本研究での MVC 時における Dig, SCM の筋活動の減少はDig が $\mathrm{Mm}$ の拮抗筋であること ${ }^{24)}$ ，大きな負荷時の SCM の筋

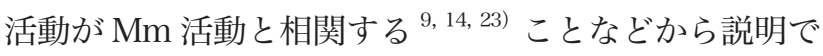
きると考える。

2) Mm, Tp, Dig, SCM における各筋間の相対的筋活 動の相関関係

$\mathrm{Mm}$ と Tp の相対的筋活動との間に正の相関が認めら れた。 Mmの浅層は下顎挙上筋として，また深層は咬 合や咬みしめのような微妙な運動に関与していると考 えられており ${ }^{25)}$ ，弱い咬みしめから最大咬みしめの付 近までは筋活動と咬合力が比例的な関係を示し, 咬合力 発揮の主役を務めるパワー筋である。一方，Tp は下顎 骨を挙上する抗重力筋であり, 筋線維が前方から後方へ と扇状に走行する筋である。本研究で EMG 活動を導出 した部位は筋線維が垂直方向に走行している $\mathrm{Tp}$ 前部と した。この筋束は収縮すると下顎が垂直方向に挙上され る. $\mathrm{Tp}$ 後部筋束は筋線維が水平方向に走行し下顎を後 方に引く作用を持っている ${ }^{26)}$. Tp の活動は前部と後部 で特徵的な活動様相を呈し, 下顎位の固定と上下顎歯が 咬み合わせてものを粉砕する動きに強く関わっている。 $\mathrm{Tp}$ の前部と後部は下顎の水平的位置に応じて特徵的な 活動様相を示し，下顎の位置を制御する役割を果たして いるとともに非常に強力な筋である。すなわち $\mathrm{Mm}$ と $\mathrm{Tp}$ は同種のパワー筋であることなどから $\mathrm{Mm}$ と $\mathrm{Tp}$ と の間の強い正の相関を説明することができると考える.

咬合機能時の SCM の機能は頭位保持という tonic な 筋線維を主体とした活動であると考えられている ${ }^{9,10)}$. $\mathrm{SCM}$ と Mm との間にも正の相関が認められた。 SCM は咀嚼時, 咬みしめ時, 開口時などに筋活動が認められ ている ${ }^{9,10,14)}$ 。すなわち, 咀嚼運動時の SCM の筋活動 は咀嚼周期の咬合相に同期して $\mathrm{Mm}$ の $\mathrm{EMG}$ 電位の $1 / 4$ 〜 1/5 の活動を示す ${ }^{10)}$. この筋活動は咀嚼側が非咀嚼 側に対して優性であり, 食品の硬度とともに増大し, $\mathrm{Mm}$ の筋活動に比例した変化様相を示す ${ }^{10,11)}$. また, 咬みしめ時にみられる SCM 筋活動は低咬合力域で微小 な増加傾向を示すのみであるが，最大咬合力の $80 \%$ 以 上の咬合力が加わると急激な上昇を示し, 頭部の後屈や 旋回時とほぼ同等の筋活動を記録できる ${ }^{14)}$. SCM には このような様相変化があること, また咬合機能時には頭 
部を体幹に固定することが必要であることなどから $\mathrm{SCM}$ と Mm との正の相関関係を説明できる.

Dig は Mm との間に正の相関が認められた。このこ とは最大咬みしめ時においても開口筋である Dig が $\mathrm{Mm}$ や Tp の拮抗筋として働いていること ${ }^{24)}$ を窺わせ る現象と考える.

3) MVC 時と With MVC 時における Mm, Tp, Dig, SCM の筋活動量

Mm の筋活動は With MVCが MVC より有意に大き くなったが, Tp, Dig, SCM においては有意差が見られ なかった. $\mathrm{Mm}$ と $\mathrm{Tp}$ の筋活動様相の違いは最大咬みし め時, Mm が Tp に比較して咬合力を発揮する force generator としての機能がより強く働き，一方，Tpは 弱い咬みしめ負荷の時には positioner としての機能が より強く働き, 最大咬みしめのような強い負荷時には Mm を助けて force generator としての機能をより強く 発揮するようになり, positioner としての機能が相対的 に小さくなる ${ }^{27)}$ と推論するならば，Mm では With MVC 時には force generator としての機能がより強く働 いたと解釈できるであろう。

\section{4）FG と MG における各筋の相対的筋活動}

$\mathrm{Mm}$ ならびに Tp の相対的筋活動では FG と MG の間 に有意差があり, MGが FGに比べて大きい值を示した. この結果は shim stock で検出した咬頭嵌合位の咬合接 触数の多い群が少ない群よりも $\mathrm{Mm}, \mathrm{Tp}$ の活動が大き くなったと報告している Ferrario ら ${ }^{28)}$ の結果と一致す るものの, Ferrario らはこの様相について言及していな い. クレンチング時の $\mathrm{Mm}$, Tp の筋活動量は咬合力と ほぼ直線的な相関関係があり咬合力を知る目安として 利用されている。したがって本研究の結果から，MGの 咬合力は FGのそれよりも大きいことが推察される。ま た，SCM の相対的筋活動では有意に MG が FG に比べ て大きい值となった，FGの咬頭嵌合位における $\mathrm{Mm}$, Tp, SCM の相対的筋活動がそれぞれ 0.76, 0.84, 0.85 で あったことは, MVC 時の筋活動が With MVC に比べ Mm では 24\%, Tp では 16\%, SCM では 15\% 減少し たことを，また MG の Mm, Tp, SCM の相対的筋活動 がそれぞれ 1.06，1.10，1.07であったことは MVC 時 の筋活動が With MVC に比べ 6〜 10\%増加したことを 示している. また, Dig の相対的筋活動は FGで 0.81 , MG で 0.89 であった。この様相は MVC 時の筋活動が With MVCに比べ 11 19\%減少したことを意味して いる.

クレンチング時の左右側 $\mathrm{Mm}, \mathrm{Tp}$ 前部および $\mathrm{Tp}$ 後
部の筋活動は水平的下顎位の位置的変化によって特徵 的に変化する現象から水平的下顎位を決める指標とす る方法も提案 ${ }^{29)}$ されている。すなわち，この方法は咬 頭嵌合位において最大の筋活動量を示し，下顎位が偏位 すると Mm およびTp の筋活動は大きく減少するとい う根拠に基づいている。したがって，このような観点か らも MVC 時における $\mathrm{Mm}, \mathrm{Tp}, \mathrm{SCM}$ の筋活動量は咬合 接触数が関連している現象と考える。しかしながら，こ れらについては更なる検討が必要である.

\section{V. 結 論}

咬合機能時における咬筋，側頭筋，顎二腹筋，煩鎖乳 突筋の筋活動量の関連性を明らかにするために，健常有 歯䫈者 20 名の咬頭嵌合位における最大咬みしめ (MVC) とコットンロール介在の最大咬みしめ (With MVC) 時 の咬筋，側頭筋，顎二腹筋ならびに胸鎖乳突筋の筋活動 について筋電図を用いて測定し, 各筋の筋活動の特徵と 筋間の相互関係を調べるとともに，筋活動量と咬頭嵌合 位における咬合接触数との関連を検討し，以下の結果を 得た。

1. 咬筋，側頭筋，顎二腹筋ならびに胸鎖孚突筋におけ る相対的筋活動は各筋間に有意差を認めなかった。

MVC 時の咬筋，顎二腹筋，胸鎖乳突筋の筋活動は With MVC 時の筋活動と比較して 11 14\%減少した。 一方, Tp では変化が少なかった。

2. 各筋間の相対的筋活動は，咬筋と側頭筋，顎二腹筋， 胸鎖乳突筋との間に正の相関を認めたが，側頭筋と 顎二腹筋，側頭筋と胸鎖乳突筋，顎二腹筋と胸鎖乳 突筋との間には相関を認めなかった。

3. MVC と With MVC 時における筋活動量は，咬筋で はMVCが With MVC に比べて有意に小さい值を示 したが，側頭筋，顎二腹筋，胸鎖乳突筋においては MVC と With MVC との間に有意差を認めなかった。

4. 咬合接触数少数群 (FG) と咬合接触多数群 (MG) における各筋の相対的筋活動は咬筋，側頭筋，胸鎖 乳突筋において MG が FG に比べて有意に大きい值 を示したが，顎二腹筋においては MG と FG との間 に有意差を認めなかった。

\section{文献}

1) McDevitt WE, Warreth AA. Occlusal contacts in maximum intercuspation in normal dentitions. J Oral Rehabil 1997; 24: 725-734

2) 日本補綴歯科学会編。第 2 版 歯科補綴学専門用語集, 
東京: 医歯薬出版 ; 2004, p.37.

3) MacDonald JW, Hannam AG. Relationship between occlusal contacts and jaw-closing muscle activity during tooth clenching: Part II. J Prosthet Dent 1984; 52: 862-867.

4) Bakke M, Michler L, Moller E. Occlusal control of mandibular elevator muscles.Scand J Dent Res 1992; 100: 284-291.

5) Hidaka $O$, Iwasaki $M$, Saito $M$ et al. Influence of clenching intensity on bite force balance, occlusal contact area, and average bite pressure. J Dent Res 1999; 78: 1336-1344.

6）三谷春保, 藤井弘之. 咀嚼筋の筋電図とその臨床応用. 東京医科歯科大学歯学部顎口腔機能総合研究施設編. 顎運動とそのメカニズム，東京：日本歯科評論社； 1976, p.240-263.

7）中村嘉男. 咀嚼運動のしくみ. 東京医科歯科大学歯学 部顎口腔機能総合研究施設編。咀嚼の話，東京：日本歯 科評論社 ; 1983, p.259-300.

8) Clark GT, Green EM, Dorman RM et al. Craniocervical dysfunction levels in a patient sample from a tenporomandibular joint clinic. J Am Dent Assoc 1987; 115: 251-256.

9）河野正司，吉田恵一，小林博ほか. 咬合機能時に見られ る胸鎖乳突筋の活動様相。補綴誌 1987; 31：764-769.

10）吉田恵一，咬合機能時における胸鎖乳突筋の機能に関 する筋電図学的解析. 口病誌 1988; 55: 53-70.

11) Clark GT, Browne PA, Nakano M et al. Co- activation of sternocleidomastoid muscles during maximum clenching. J Dent Ress 1993; 72: 1499-1502.

12) 河野正司. 咀嚼筋。長谷川成男, 坂東永一監修。臨床 咬合学辞典，東京 : 医歯薬出版；1997, p.67.

13）三井靖徳，波多野泰夫，横塚繁雄。顎関節症診査のため の圧痛検査部位に関する研究. 歯学 1993; 81: 681-704.

14）佐藤康弘。種々の咬合機能時にみられる胸鎖乳突筋の Co-activation の特徵について. 顎機能 1993; 11: 78-86.

15) Anderson GC, Schulte JK, Aeppli DM. Reliability of the evaluation of occlusal contacts in the intercuspal position. J Prosthet Dent 1993; 70: 320-323.

16) Ogawa $T$, Ogimoto T, Koyano K. Pattern of occlusal contacts in lateral positions: canine protection and group function validity in classifying guidance patterns. J Prosthet Dent 1998; 80: 67-74.
17) Riise C, Ericsson SG. A clinical study of the distribution of occlusal tooth contacts in the intercupal position at light and hard pressure in adults. J Oral Rehabil 1983; 10: 473-480.

18) Berry DC, Singh BP. Daily variations in occlusal contacts. J Prosthet Dent 1983; 50: 386-391.

19) Molligoda MA, Berry DC, Gooding PG. Measuring diurnal variations in occlusal contact areas. J Prosthet Dent 1986; 56: 487-492.

20) Baba K, Tsukiyama Y, Clark GT. Reliability, validity, and utility of various occlusal measurement methods and techniques. J Prosthet Dent 2000; 83: 83-89.

21) Tryde G, Frydenberg O, Brill N. An assessment of the tactile sensibility in human teeth. Acta Odont Scand 1962; 20: 233-256.

22) Kapandji IA. カパンディ関節の生理学III体幹, 脊柱, 東京: 医歯薬出版 ; 1986, p.212.

23）河野正司，坂東永一，田中 伐ほか。咀嚼筋の筋活動を 指標とした咬合位の推定. 補綴誌 1982; 26: 1271-1286.

24) Inoko Y, Yoshimura K, Morita O. Characteristics of the perioral muscle electromyographic activities during jaw functions in healthy young adults. Prosthodont Res Pract 2006; 5: 166-170.

25）保母須弥世編. 新編咬合事典, 東京 : クインテッセンス 出版 ; 1998, p.232-233.

26）保母須弥世編．新編咬合事典，東京：クインテッセンス 出版; 1998, p.471-472.

27）佐藤 斉。咬みしめ負荷における下顎位の安定状態の 違いが咀嚼筋活動に及ぼす影響。補綴誌 1994; 38: 788-798.

28) Ferrario VF, Serrao G, Dellavia C et al. Relationship between the number of occlusal contacts and masticatory muscle activity in healthy young adults. Cranio 2002; 20: 91-98.

29）日本補綴歯科学会編。第 2 版歯科補綴学専門用語集, 東京 : 医歯薬出版 ; 2004, p.23.

\footnotetext{
著者連絡先 : 猪子 芳美

干 951-8580 新潟県新潟市中央区浜浦町 1-8 TEL : 025-267-1500（内 313)

FAX : 025-267-8906

E-mail : yinoko@ngt.ndu.ac.jp
} 


\title{
Relationship between the Number of Occlusal Contacts in Intercuspal Position and the Jaw and the Sternocleidomastoid Muscle Activities during Maximum Voluntary Teeth Clenching
}

\author{
Norio Ohnuma, DDS, PhD, ${ }^{\mathrm{a}}$ Yoshimi Inoko, DDS, PhD, ${ }^{\mathrm{b}}$ and Osami Morita, DDS, $\mathrm{PhD}{ }^{\mathrm{b}}$ \\ ${ }^{a}$ Department of Comprehensive Dental Care, The Nippon Dental University Niigata Hospital \\ ${ }^{b}$ Department of Complete Denture, The Nippon Dental University, School of Life Dentistry at Niigata
}

Ann Jpn Prosthodont Soc $1: 38-45,2009$

\section{ABSTRACT}

Purpose: The aim of the present study was to clarify the relationship between the number of occlusal contacts in the intercuspal position and the jaw and sternocleidomastoid muscle activity during maximum voluntary teeth clenching in healthy young subjects.

Methods: This study included 20 healthy subjects ( 7 women and 13 men). They had natural dentition and bilateral molar support. The electromyographic (EMG) potential of the masseter, temporalis, and anterior belly of the digastric and sternocleidomastoid muscles was recording during: 1) a 3-second maximum voluntary clenching (MVC) on cotton rolls positioned on the posterior teeth (standardized recording), and 2) a 3-second MVC in the intercuspal position. EMG potentials recorded in the intercuspal position were standardized as a percentage of the mean potentials of the standardized recording, and the EMG muscle activity was calculated. The number of occlusal contacts in the intercuspal position was assessed using 12 - $\mu \mathrm{m}$ thick shim stocks. Ten subjects with fewer than 8 occlusal contacts (few contacts) and 10 with at least 9 occlusal contacts (multiple contacts) were selected and grouped accordingly.

Results: Significant relationships between the masseter and temporalis, and anterior belly of the digastric and sternocleidomastoid muscles in standardized values $(P<0.05)$ were found. The MVC recorded in the masseter, temporalis, and sternocleidomastoid muscles in the "multiple contacts" group was significantly greater than that recorded in the "few contacts" group $(P<0.05)$.

Conclusion: We conclude that the number of occlusal contacts in the intercuspal position is significantly related to jaw and sternocleidomastoid muscle activity in healthy young adults.

\section{Key words}

occlusal contact, jaw muscle, sternocleidomastoid muscle, electromyography(EMG) 